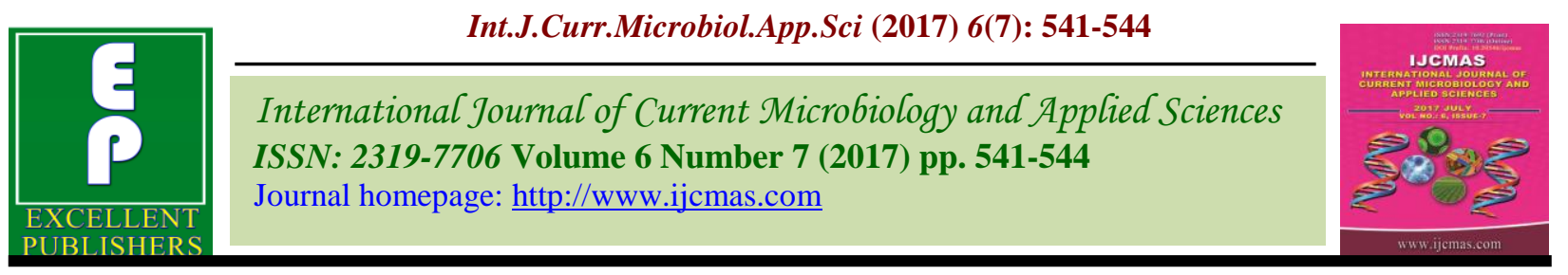

Original Research Article

https://doi.org/10.20546/ijcmas.2017.607.065

\title{
Evaluation of Hirsutum Cotton Varieties under Various Fertility Levels and Plant Geometries
}

\author{
Harphool Meena*, P.K.P. Meena and Bheru Lal Kumhar \\ Agricultural Research Station, Ummedganj Farm Agriculture University, Kota-324001, \\ Rajasthan, India \\ *Corresponding author
}

\begin{tabular}{|c|c|}
\hline & A B S T R A C T \\
\hline & An experiment was conducted at Agricultural Research Station, Borwat Farm, \\
\hline Keywords & $\begin{array}{l}\text { Banswara to evaluate the hirsutum cotton hybrids under various pant geometries } \\
\text { and fertility levels Sowing of } \mathrm{H}-8 \text { cotton hybrid gave significantly higher seed }\end{array}$ \\
\hline Hirsutum cotton, & cotton yield $\left(2274 \mathrm{~kg} \mathrm{ha}^{-1}\right)$ over RAHH-259 $\left(1827 \mathrm{~kg} \mathrm{ha}^{-1}\right)$. The maximum seed \\
\hline & $\begin{array}{l}\text { cotton yleld (20/6 kg ha ) was observed under plant geometry of } 90 \times 45 \mathrm{~cm} \text { than } \\
\text { wider plant geometry of } 90 \times 60 \mathrm{~cm}\left(1808 \mathrm{~kg} \mathrm{ha}^{-1}\right) \text { and } 90 \times 90 \mathrm{~cm}\left(1735 \mathrm{~kg} \mathrm{ha}^{-1}\right) \text {. }\end{array}$ \\
\hline and fertility levels. & Though, yield attributing parameters such as bolls plan $^{-1}$ and boll weight were \\
\hline Article Info & statically improved in wider as compared to closer spacing but it could not \\
\hline $\begin{array}{l}\text { Accepted: } \\
\text { 04 June } 2017 \\
\text { Available Online: } \\
10 \text { July } 2017\end{array}$ & $\begin{array}{l}\text { Among fertility levels, similar seed cotton yield was recorded with the application } \\
\text { of } 100 \% \text { RDF }\left(2079 \mathrm{~kg} \mathrm{ha}^{-1}\right) \text { and } 125 \% \text { RDF }\left(2108 \mathrm{~kg} \mathrm{ha}^{-1}\right) \text { but both were } \\
\text { significantly better than that application of } 75 \% \text { RDF and plant geometry } 90 \times 45\end{array}$ \\
\hline & under the specific agro climatic zone IV b of Rajasthan. \\
\hline
\end{tabular}

\section{Introduction}

Cotton is known as white gold and queen of fibers. It is an important cash crop of global significance which plays a dominant role in world agriculture and industrial economy. India is important grower of cotton on a global scale. The cotton productivity in 201617 has $568 \mathrm{~kg} / \mathrm{ha}$ with an area of 105 lakh ha and production 351 lakh bales each $170 \mathrm{~kg}$ (http://cotcorp.gov.in/statistics.aspx\#area CCI, 2017).

Cotton productivity depends on various factors among them selection of potential genotypes along with plant densities play a vital role in increasing the productivity of cotton. The manipulation of row spacing, plant density and the spatial arrangements of cotton plants, for obtaining higher yield have been attempted by agronomists for several decades in many countries. The most commonly tested plant densities range from 5 to 15 plants $/ \mathrm{m}^{2}$ (Kerby et al., 1990) resulting in a population of 50000 to 150000 plants/ha.

The maximum exploitation of these genotypes can be achieved only after determining their optimum planting densities in comparison to recommended cotton varieties. In general, it 
was observed that lower plant densities produces high values of growth and yield attributes per plant, but yield per unit area was higher with higher plant densities (Sharma et al., 2001). However, it may happen that moderate increase in plant densities may not increase the yield but decrease due to competition between plants for nutrients, water, space and light (Nehra and Kumawat, 2003).

The reasons for decreasing productivity are due to decreasing soil fertility especially micronutrients, imbalanced use of fertilizer and occurrences of physiological disorders like square dropping, square drying, leaf reddening etc. Among these, imbalanced use of major and micro nutrients is the major problem (Hebbar et al., 2007). To overcome these constraints, additional nutrition through foliar feeding is required over and above the normal fertilizer recommendation. This is one of the most efficient ways of supplying essential nutrients to a growing crop. Newly released, high yielding transgenic cotton cultivars are said to have a higher nutrient demand during the boll development period (between flowering and maturity) due to their higher boll retention rate and larger boll load than conventional cultivars (Sawan et al., 2008). Therefore, supplying optimal quantities of mineral nutrients and using balanced macro and micronutrient doses to growing crop plants is one way to improve crop yields.

\section{Materials and Methods}

Field experiment was conducted during kharif -2012 at Agricultural Research Station, Borwat Farm, Banswara. The eighteen treatment combinations comprised of two cotton hybrids (H-8 and RAHH-259) in main plot, three plant geometries $(90 \times 45,90 \times 60$ and $90 \times 90 \mathrm{~cm}$ ) in sub plot and three fertility levels $(75,100$ and $125 \%$ RDF) in sub-sub plot under split plot design with four replications. Experimental field was well prepared by two ploughing followed by harrowing and cultivator and one planking for uniform levelling were performed for sowing of cotton.

The soil was medium in available nitrogen (244 kg/ha), phosphorus (48 kg/ha) and high in available potassium $(327 \mathrm{~kg} / \mathrm{ha})$ during the crop season. The crop was sown in second week of June by dibbling 2-3 seeds per hills and full dose of phosphorus and potash were applied before sowing, while nitrogen dose was given in two splits i.e. first half at the time of thinning and remaining half at flowering stage. All production and protection measures were applied as per package of the zone IV b.

\section{Growth}

Data shows that the sowing of hirsutum cotton, among the cotton hybrids the H-8 was proved superior over RAHH-259. Cotton hybrid H-8 gave higher plant height (108.40 $\mathrm{cm})$, monopodial branches plant ${ }^{-1}(1.24)$, and sympodial branches plant ${ }^{-1}$ (17.02) as compared to RAHH-259. The wider plant spacing $90 \times 60 \mathrm{~cm}$ and $90 \times 90 \mathrm{~cm}$ were found at par with each other, gave significantly higher plant height (109.20 and $112.07 \mathrm{~cm})$, monopodial branches plant ${ }^{-1}(1.13$ and 1.17) and sympodial branches plant $^{-1}$ (15.23 and 16.02) over sowing at $90 \times 45 \mathrm{~cm}$ plant spacing.

Significantly increase the growth of cotton with the increasing of fertility levels, application of $100 \% \mathrm{RDF}$ and $125 \% \mathrm{RDF}$ were found at par with each other. The maximum plant height $(107.40 \mathrm{~cm})$, monopodial branches $\operatorname{plant}^{-1}(1.16)$ and sympodial branches plant ${ }^{-1}$ (13.90) were observed under application of $100 \%$ RDF over application of $75 \%$ RDF plant height 
(99.05 cm), monopodial branches plant $^{-1}$ (1.05) and sympodial branches plant ${ }^{-1}$ (12.03). Height increase could be due to competition for solar radiation, water and nutrient uptake among the plants. Besides leaf production was associated with plant height changes (Gao and Jein, 1989). Plant height and seed cotton yield was positively correlated with the plant spacing (Ganvir et al., 2013).

\section{Yield attributes}

Cotton hybrid H-8 gave higher bolls plant ${ }^{-1}$ (23.27), boll weight (4.32) over RAHH-259 bolls plant ${ }^{-1}$ (18.14), boll weight (3.71). The wider plant spacing $90 \times 60$ and $90 \times 90 \mathrm{~cm}$ gave significantly higher bolls plant ${ }^{-1}(21.52$ and 22.05), boll weight (4.10 and 4.17) over sowing at $90 \times 45 \mathrm{~cm}$ plant spacing bolls plant $^{-1}$ (17.49), boll weight (3.80).Application of $100 \% \mathrm{RDF}$ and $125 \% \mathrm{RDF}$ were found at par with each other. The maximum bolls plant $^{-1}$ (20.28), boll weight (3.97) were observed under application of $100 \%$ RDF over application of $75 \%$ RDF bolls plant ${ }^{-1}$ (16.56), boll weight (3.55). Application of NPK leads to increase bolls/plant, boll weight due to accelerated mobility of photosynthates from source to sink Similar observations were also made by Siddiqui et al., 2009 and Sasthri et al., 2000.

Table.1 Effect of plant geometry and fertility levels on growth, yield attributes and seed cotton yield of hirsutum cotton

\begin{tabular}{|c|c|c|c|c|c|c|}
\hline Treatment & $\begin{array}{c}\text { Plant } \\
\text { height } \\
\text { (cm) }\end{array}$ & $\begin{array}{c}\text { Monopodial } \\
\text { branches / } \\
\text { plant }\end{array}$ & $\begin{array}{c}\text { Sympodial } \\
\text { branches / } \\
\text { plant }\end{array}$ & $\begin{array}{c}\text { Bolls } \\
\text { / plant }\end{array}$ & $\begin{array}{c}\text { Boll } \\
\text { weight } \\
\text { (g) }\end{array}$ & $\begin{array}{c}\text { Seed } \\
\text { cotton } \\
\text { yield } \\
(\mathbf{k g} / \mathrm{ha})\end{array}$ \\
\hline \multicolumn{7}{|l|}{ Variety } \\
\hline $\mathrm{H}-8$ & 108.40 & 1.24 & 17.02 & 23.27 & 4.32 & 2274 \\
\hline RAHH-259 & 98.15 & 1.08 & 15.70 & 18.14 & 3.71 & 1827 \\
\hline SEm \pm & 1.69 & 0.04 & 0.45 & 1.25 & 0.17 & 74 \\
\hline $\mathrm{CD}(\mathrm{p}=0.05)$ & 5.27 & 0.13 & 1.32 & 3.68 & 0.50 & 218 \\
\hline \multicolumn{7}{|c|}{ Plant geometry } \\
\hline $90 \times 45 \mathrm{~cm}$ & 103.04 & 1.05 & 13.12 & 17.49 & 3.80 & 2076 \\
\hline $90 \times 60 \mathrm{~cm}$ & 109.20 & 1.13 & 15.23 & 21.52 & 4.10 & 1808 \\
\hline $90 \times 90 \mathrm{~cm}$ & 112.07 & 1.17 & 16.02 & 22.05 & 4.17 & 1735 \\
\hline $\mathrm{SEm} \pm$ & 1.74 & 0.02 & 0.39 & 1.03 & 0.09 & 70 \\
\hline $\mathrm{CD}(\mathrm{p}=0.05)$ & 5.04 & 0.06 & 1.20 & 3.11 & 0.26 & 209 \\
\hline \multicolumn{7}{|c|}{ Fertility levels } \\
\hline $75 \%$ RDF & 99.05 & 1.05 & 12.03 & 16.56 & 3.55 & 1785 \\
\hline $100 \% \mathrm{RDF}$ & 107.40 & 1.16 & 13.90 & 20.28 & 3.97 & 2079 \\
\hline $125 \% \mathrm{RDF}$ & 109.36 & 1.18 & 14.48 & 22.42 & 4.01 & 2108 \\
\hline SEm \pm & 1.80 & 0.03 & 0.42 & 1.12 & 0.11 & 82 \\
\hline $\mathrm{CD}(\mathrm{p}=0.05)$ & 5.52 & 0.08 & 1.26 & 3.30 & 0.34 & 243 \\
\hline
\end{tabular}

\section{Seed cotton yield}

Sowing of cotton hybrids $\mathrm{H}-8$ gave significantly higher seed cotton yield (2274 $\left.\mathrm{kg} \mathrm{ha}{ }^{-1}\right)$ over sowing of RAHH-259 (1827 kg $\left.\mathrm{ha}^{-1}\right)$. Significantly higher seed cotton yield $\left(2076 \mathrm{~kg} \mathrm{ha}^{-1}\right)$ was recorded under sowing at $90 \times 45 \mathrm{~cm}$ plant spacing over sowing at 
wider plant spacing at $90 \times 60$ and $90 \times 90 \mathrm{~cm}$ seed cotton yield (1808 and $1735 \mathrm{~kg} \mathrm{ha}^{-1}$ ). Application of $100 \% \mathrm{RDF}$ and $125 \% \mathrm{RDF}$ were found at par with each other. The maximum seed cotton yield $\left(2079 \mathrm{~kg} \mathrm{ha}^{-1}\right)$ was found under application of $100 \% \mathrm{RDF}$ over application of $75 \% \mathrm{RDF}$ seed cotton yield $\left(1785 \mathrm{~kg} \mathrm{ha}^{-1}\right)$, the difference between a narrow row and a wide row was not significant on yield but a wider row may facilitate intercultural (Table 1).

Earlier, Heitholt et al., (1996) observed that at equal densities, narrow row may allow each plant to intercept more light and increase seasonal light interception but this advantage is seldom translated into improvements in yield. These above are in accordance with those obtained by Gao and Jein (1989), Ganvir et al., (2013), Nehra and Kumawat, (2003) and Sharma et al., (2001).

It can be concluded that Hybrid-8 proved superior with $90 \times 45 \mathrm{~cm}$ plant spacing and $100 \%$ RDF over RAHH-259 in respect of yield and yield attributes.

\section{References}

CCI. Cotton Advisory Board (CAB) 2017.

Ganvir, S., Ghanbahadur, $M$ and Khargkharate, V.K. 2013. Response of hirsutum cotton to high plant density, fertilizers and moisture conservation. Annals of Plant Physiology. 27 (1): 33-37.

Gao, Q and Jein, J.S. 1989. A study of cultivation model for high quality and yield in cotton using leaf observation. The relationship between leaf order and organ formation in cotton. Journal of Nanjing Agriculture University. 4: 1-8.
Hebbar, K. B., Perumal, N. K. and Khadi, B. M. 2007. Photosynthesis and plant growth response of transgenic Bt cotton (Gossypium hirsutum L.) hybrids under field condition. Photosynthetica, 45(2): 254-258.

Heitholt, J. J., Meredith, W. R., Jr. and Williford, J.R. 1996. Comparison of cotton genotypes varying in canopy characteristics in $76-\mathrm{cm}$ and 102-cm rows - Crop Science. 36: 955960.

IBGE. (2010). The Brazilian Institute of Geography and Statistics.

Kerby, T.A., K.G. Cassman; and M. Keekey, 1990. Genotypes and plant densities for narrowrow cotton system. I. Height, nodes, earliness, and location of yield - Crop Science, 30:645-649.

Nehra, P.L. and Kumawat, P.D. 2003. Response of hirsutum cotton varieties to spacing and nitrogen levels. J. Cotton Res. Dev., 17(1): 41-42.

Sashtri, G., Thagarajan, C. P., Srimathi, P., Malarkodi, K. and Venkatasalam, E. P. 2000. Foliar application of nutrient on the seed yield and quality characters of non-aged and aged seeds of cotton cv. MCUS. Madras Agricultural J., 87: 4/6), 202-206.

Sawan, Z. M., Mahmoud, M. H. and El-Guibali, A. H. 2008. Influence of potassium fertilization and foliar application of zinc and phosphorus on growth, yield components, yield and fiber properties of Egyptian cotton (Gossypium barbadense L.). J. Plant Ecol.1: 259-70.

Sharma, J.K., Upadhayay, Mishra, U.S., Khamparia, S.K., and Andloi, K.C.M. 2001.Effect of spacing and fertility levels on growth and yield of hirsutum genotypes. $J$. Cotton Res. Dev., 15(2): 151-153.

Siddiqui, M.H., Oad, F.C., Abbasi, M.K. and Gandahi, A.W. 2009. Zinc and boron fertility to optimize physiological parameters nutrient uptake and seed yield of sunflower. Sarhad J. Agric, 25:53- 57.

\section{How to cite this article:}

Harphool Meena, P.K.P. Meena and Bheru Lal Kumhar. 2017. Evaluation of Hirsutum Cotton Varieties under Various Fertility Levels and Plant Geometries. Int.J.Curr.Microbiol.App.Sci. 6(7): 541-544. doi: https://doi.org/10.20546/ijcmas.2017.607.065 